\title{
SHORT-TERM IMPACT OF AMMONIUM NITRATE AND WOOD ASH APPLICATION ON GROUND VEGETATION DIVERSITY AND SPECIES COMPOSITION IN DRAINED FORESTS
}

\author{
Guna PETAJA, Latvian State Forest Research Institute “Silava”, Rigas street 111, LV-2169 Salaspils, Latvia; guna.petaja@silava.lv \\ (corresponding author) \\ Zaiga ZVAIGZNE, Latvian State Forest Research Institute "Silava", Rigas street 111, LV-2169 Salaspils, Latvia; \\ zaiga.zvaigzne@silava.lv
}

Fertilization is a way of improving tree growth and thus profitability of forestry, however this practice may cause negative side effects, such as loss of biodiversity. Ground vegetation represents a major part of plant biodiversity in forest and it is sensitive to environmental changes. The aim of the study was to characterize a short-term impact of ammonium nitrate and wood ash application on floristic composition and species diversity in conifer and deciduous forests on drained mineral and peat soils. The study was conducted in 6 stands representing Myrtillosa, Myrtillosa turf.mel., Vacciniosa mel. and Vacciniosa turf. mel. forest types. The projective cover of each species was estimated visually, separately for moss, herb and shrub layer. Shannon diversity index, species richness and species composition were compared between the plots, where fertilizers were added, and control plots. Results show that species composition corresponds to the respective forest types regardless of the application of fertilizers. In all of the surveyed stands several nitrophilous species were more frequently observed and had a slightly larger projective cover in treatment plots, which could be explained by the impact of fertilization. Species diversity in the moss layer might have lowered as a result of fertilization, whereas no consistent patterns were observed for the herb layer. A repeated survey will show, if changes in ground vegetation persist longer.

Keywords: ammonium nitrate, drained forests, ground vegetation, species diversity, species richness, wood ash

\section{INTRODUCTION}

Ground vegetation is an important aspect of forest ecosystems. The herbaceous layer contains $90 \%$ of forest plant species and also has higher extinction rates than other layers (Gilliam, 2007). In the United Nations Convention on Biological diversity, the term "biodiversity" is defined as: "the variability among living organisms from all sources including, inter alia, terrestrial, marine and other aquatic ecosystems and the ecological complexes of which they are part; this includes diversity within species, between species and of ecosystems"( Biosafety Convention Text..., 2006). In the recent years forest management is expected to be sustainable, taking biodiversity into consideration.

Forest fertilization is an effective tool to increase forest production. In boreal forests on mineral soils, nitrogen containing fertilizers are mostly applied, whereas in peatland forests potassium and phosphorus fertilizers are most commonly used (Saarsalmi and Mälkönen, 2001). The dose of nitrogen typically applied to forests is $150 \mathrm{~kg} / \mathrm{ha}$ and the growth response is 20-25 $\mathrm{m}^{3} \mathrm{ha}^{-1}$ (Pukkala, 2017). The largest growth improvement is mostly observed within the first 5 years, however the effect of fertilization lasts about 10-12 years (Saarsalmi and Mälkönen, 2001).

Wood ash is the inorganic residue that remains after biomass combustion. Instead of landfilling it can be recycled in several ways, e.g., used as a fertilizer, because it contains all the nutrients necessary for plant growth except for nitrogen (Pitman, 2006). It already has been used to amend nitrogen-rich peatland forests in Finland and to reduce soil acidity in forests on mineral soils on Sweden (Vesterinen, 2003). Also in Latvia studies have been conducted to investigate the effect of wood ash on tree growth and the results showed a positive effect on Norway spruce growth on drained mineral and peat soil (Okmanis et al., 2016). In case of soils that are poor in nitrogen wood ash fertilization alone does not significantly improve tree growth, therefore it is advisable to apply wood ash together with nitrogen-containing fertilizers, such as ammonium nitrate (Jacobson, 2003). The effect of wood ash is longer than that of nitrogen fertilizer (20-50 years) (Pitman, 2006).

While application of fertilizers improves tree stem growth, it may have a negative effect on ground vegetation. Excessive nitrogen input is considered one of the main contributors to biodiversity loss in Europe (Dise et al., 2011). N is the limiting nutrient in boreal and temperate forests. Nitrogen addition to forest soils favours certain species by increasing their cover or invasion of new species, e.g. nitrophilous Urtica dioica, Impatiens parviflora, Geranium robertianum, while eliminating or decreasing occurrence of species that are adapted to N-poor environments (lichens, ericaceous dwarf shrubs, orchids) (Buriánek et al., 2013). Amending soil with wood ash increases soil pH along with increasing nutrient levels. The most sensitive to wood ash application appear to be mosses and lichens, whose cover normally decreases. Studies show that the cover of Pleurozium schreberi and Dicranum polysetum as well as lichens 
Cladonia sp. and Cladina sp. has decreased after wood ash application, whereas that of the calciphilous moss Pohlia nutans has increased (Kellner and Weibull, 1998). Regarding the herb and the shrub layer, the cover of forbs Trientalis europaea, Epilobium angustifolium, Melampyrum sp. and Taraxacum sp., grasses Deschampsia flexuosa and Luzula pilosa as well as the shrub Rubus ideaus increased and that of dwarf shrubs Vaccinium myrtillus, Vaccinium vitis-idaea and Calluna vulgaris decreased as a result of wood ash application (Olsson and Kellner, 2002). The overall impact of species diversity is small. Arvidsson et al. observed a slight increase in diversity after application of wood ash.

So far studies on the impact of forest fertilization on ground vegetation in Latvia are insufficient. Therefore in this study we investigated, how application of nitrogen fertilizer - ammonium nitrate - and wood ash influences species diversity, species richness and species composition of ground vegetation in drained forests - Myrtillosa, Myrtillosa turf.mel., Vacciniosa mel. and Vacciniosa turf. mel.

\section{STUDY SITES AND METHODS}

The study was conducted in 6 forest stands with the total area of 24 ha (average area of a stand $=4$ ha), where the dominant tree species is Norway spruce (Picea abies), Scots pine (Pinus sylvestris) or Silver birch (Betula pendula), representing 4 forest types. The age of forest stands varied from 29 to 60 years. Stand characteristics are shown in table 1. In all the stands commercial thinning has been done in the recent years. The stands are managed by Latvia State Forests and Forest research station.

Table 1: Characteristics of the studied forest stands

\begin{tabular}{|l|l|l|l|}
\hline No. & Forest type & Tree species & Average stand age \\
\hline 1 & Myrtillosa mel. & Norway spruce & 33 \\
\hline 2 & Myrtillosa mel. & Silver birch & 29 \\
\hline 3 & Myrtillosa turf. mel. & Silver birch & 33 \\
\hline 4 & Myrtillosa turf. mel. & Norway spruce & 53 \\
\hline 5 & Vacciniosa turf. mel. & Scots pine & 54 \\
\hline 6 & Vacciniosa mel. & Scots pine & 60 \\
\hline
\end{tabular}

Wood ash spreading was completed in 2016 and the applied dose was $3 \mathrm{t} \mathrm{ha}^{-1}$. Ammonium nitrate $\left(\mathrm{NH}_{4} \mathrm{NO}_{3}, 0.44\right.$ $\mathrm{t} \mathrm{ha}^{-1}$ ) was spread in June - July 2017 to ensure the maximum effect, the applied dose was $100 \mathrm{~kg} \mathrm{~N}$ ha- 1 . Wood ash was taken from wood pellet plant 'NewFuels', biomass-fired heat and power plant 'Fortum' and Latgran pellet factory. Wood ash composition is shown in Table 2.

Table 2: Chemical composition of wood ash and the applied doses of elements

\begin{tabular}{|c|c|c|}
\hline Element & Concentration, $\mathrm{g} \mathrm{kg}^{-1}$ & Dose, kg ha-1 \\
\hline $\mathrm{Ca}$ & 101.7 & $203.4-406.8$ \\
\hline $\mathrm{K}$ & 16.3 & $32.6-65.2$ \\
\hline $\mathrm{Mg}$ & 16.7 & $33.4-66.8$ \\
\hline $\mathrm{P}$ & 5.1 & $10.2-20.4$ \\
\hline $\mathrm{Fe}$ & 4.1 & $8.2-16.4$ \\
\hline $\mathrm{Mn}$ & 1.3 & $2.6-5.2$ \\
\hline
\end{tabular}

Vegetation was surveyed in the summer of 2018 , in double plots of $1 \mathrm{~m}^{2}$ squares arranged in an equilateral triangle, whose edges are oriented perpendicularly to the 30x30 m plot, where fertilizers were spread. The cover of each species was estimated visually as percentage in moss (mosses and lichens), herb (herbaceous plants, dwarf shrubs, shrubs and tree seedlings up to $0.5 \mathrm{~m}$ ) and shrub (shrubs and trees at the height $0.5-7.0 \mathrm{~m}$ ) layer in both treatment and control plots. Species occurrence, species richness and species diversity were analysed and compared between control plots and treatment plots of each stand. Shannon-Wiener diversity index (H') was used as the mathematical measure of species diversity. It was calculated separately for moss, herb and shrub layer according to formula 1 (Spellerberg and Fedor 2003):

$$
H^{\prime}=-\sum\left(\frac{n_{i}}{N}\right) \log _{2}\left(\frac{n_{i}}{N}\right)
$$

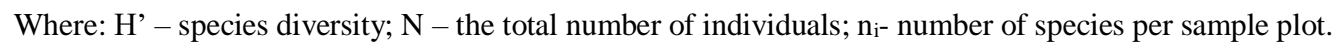

In our case percentage cover values were used in calculations instead of the number of individuals, as it has been done in several other studies, e.g. Vahdati et al. 2014. Data were processed and Shannon-Wiener diversity index was calculated in MS Excel. Statistical analysis was performed with RStudio (R version 3.2.5 and Rstudio version 1.1.463). Shapiro-Wilk test was used to determine, if data correspond to normal distribution. T-test for independent samples was used to determine, if there are statistically significant differences in H' values between control and treatment plots.

\section{RESULTS AND DISCUSSION}

\section{Myrtillosa mel. forest stands}

Myrtillosa mel. forests belong to oligomesotrophic ecosystems. The typical moss layer consists of ubiquitous feathermosses Hylocomium speldens and Pleurozium schreberi, mosses of the genera Dicranum and Rhytidiadelphus as 
well as wet and acidic habitat moss Polytrichum commune. In the surveyed Myrtillosa mel. spruce stand in the moss layer the dominant species was Pleurozium schreberi and Plagiomnium affine, which is characteristic of moist, mesoeutrophic habitats and mildly acidic soils. Hylocomium splendens, Rhytidiadelphus triquetrus, Dicranum polysetum and mesoeutrophic habitat species Rhodobryum roseum were also frequently observed, however the last two occurred only as solitary specimens with small projective cover. Only in treatment plots solitary individuals of oligomesotrophic habitat species Ptilium crista-castrensis, mesoeutrophic habitat species Cirriphyllum piliferum and eutrophic habitat species Brachythecium rutabulum were observed. In control plots 14 species were observed, whereas in treatment plots 15 species were observed. The average Shannon diversity index in control plots was larger than in treatment plots, however the difference is not statistically significant (Table 3). Also in the birch stand the most frequently observed moss species in both control and treatment plots was Plagiomnium affine. In control plots mesoeutrophic and moist habitat species Calliergonella cuspidata was more frequently observed and had a larger projective cover than in treatment plots. Only in control plots Brachythecium rutabulum, Dicranum polysetum, Pleurozium schreberi were observed. Only in treatment plots Hylocomium splendens was observed. The total moss cover was low because of the high humus content and in treatment subplots it did not exceed 6\%. The average Shannon diversity index is also low, however it is significantly higher in control plots, comparing with treatment plots $(\mathrm{p}=0.0077)$ (Table 3$)$.

The characteristic species of this forest type in the herb layer are dwarf shrubs Vaccinium mytrillus and Vaccinium vitis-idaea, grasses Molinia caerulea, Calamagrostis epigeios, Calamagrostis arundinacea and Calamagrostis canescens, shade-loving forbs Maianthemum bifolium and Anemone nemorosa and bramble Rubus saxatilis. In the spruce stand in the herb layer the most frequently observed species are Melampyrum pratense and Luzula Pilosa that indicate oligomesotrophic gowth conditons and Mycelis muralis, which prefers eutrophic habitats. Nitrophiles such as Mercurialis perennis, Mycelis muralis, Urtica dioica, which are characteristic of eutrophic habitats as well as Phragmites australis and Stellaria media, which prefer mesotrophic habitats, were more frequently observed and had a larger projective cover in treatment plots. Wet and mesotrophic habitat species Galium uliginosum is more frequently observed in control plots. Only in treatment plots calciphile Polygonatum multiflorum was observed. In total in the herb layer the number of species in control plots was 37, but in treatment plots it was 39. The average Shannon diversity index does not significantly differ between control and treatment plots and is the highest among all the surveyed stands. In the birch stand the dominant species in the herb layer is Calamagrostis canescens. In both control and treatment plots a frequently observed species were Deschampsia cespitosa, which prefers mesotrophic soils and whose cover in several subplots was $90 \%$, other oligomesotrophic and mesotrophic species: Luzula pilosa, Potentilla erecta, Maianthemum bifolium, Rubus saxatilis and nitrophile Rubus idaeus. In treatment plots the following species were more frequently observed: Scutellaria galericulata and Galeobdolon luteum which prefer eutrophic, mildly acidic to neutral soils, as well as Veronica chamaedrys, which can be observed in various habitats. Only in treatment plots Equisetum sylvaticum, Geranium robertianum, Geum rivale, Poa nemoralis were observed as well as nitrophiles Lycopus europaeus, Solanum dulcamara, Stellaria media, Urtica dioica and Fragaria vesca. All the previously mentioned species prefer growing on soils with medium to high nutrient content. Only in control plots Vaccinium myrtillus, Solidago sp., Phragmites australis, Mentha sp., Melampyrum pratense, relatively rare fern Dryopteris cristata, wet habitat species Comarum palustre, Carex sp., Anthoxanthum odoratum were observed. These species prefer acidic to mild acidic, oligotrophic to mesotrophic soils. The occurrence of most of the species was higher in treatment plots, except for calciphobous Trientalis europaea, as well as Vaccinium vitisidaea and Luzula pilosa. In total 33 species were observed in control plots and 37 species - in treatment plots. The average Shannon diversity index is significantly higher in treatment plots ( $\mathrm{p}=0.027)$ (Table 3$)$. The shrub layer consists of Corylus avellana and Frangula alnus.

\section{Myrtillosa turf.mel. forest stands}

Myrtillosa turf. mel. belong to mesoeutrophic ecosystems. The characteristic species of the moss layer are Hylocomium splendens, Pleurozium schreberi, Dicranum sp., Rhytidiadelphus, Brachythecium sp.

In the surveyed Myrtillosa turf. mel. forest stands the overall species composition is typical to the respective forest type. In the moss layer of the birch stand the most frequently observed species in both control and treatment plots is Calliergonella cuspidata, which is typical to moist oligothrophic forests. In the birch stand only in control plots mildly acidic habitat species Dicranum polysetum, Dicranum scoparium and Rhytidiadelphus triquetrus, Brachythecium rutabulum, acidic, oligotrophic to oligomesotrophic habitat species Polytrichum commune, Sphagnum angustifolium and Sphagnum squarrosum as well as solitary individuals of moist habitat species Plagiochila asplenioides, Plagiomnium ellipticum and Rhodobryum roseum were observed. Sphagnum squarrosum formed a considerably large percentage cover in 2 subplots of the control plots (50\% and 40\%). These species indicate a wet habitat. Only in treatment plots in the birch stand solitary individuals of Climacium dendroides and Plagiomnium cuspidatum, which prefers base-rich, damp habitats, were observed. Only in treatment plots in the spruce stand Dicranum scoparium was observed. In the birch stand the total number of moss species in control plots was 14, but in treatment plots it was considerably lower - only 6 species. The average Shannon diversity index in the moss layer in the birch stand in control plots was significantly higher than in treatment plots $(\mathrm{p}=0.000052)$. In the spruce stand the dominant species in the moss layer is Plagiomnium affine. Other frequently observed species in the spruce stand were ubiquitous feathermoss Pleurozium schreberi and Plagiomnium ellipticum, which prefers acidic, wet habitats and forms a larger cover in control plots. Eurhynchium hians was observed only in the spruce stand. It is an eutrophic species, growing on bare soil in base-rich habitats, not commonly observed in Myrtillosa turf. mel. forests. The Ellenberg indicator value for light of this species is 7, which means that it prefers growing in full light and this could explain, why it is more frequently observed in control plots. In the spruce stand the average 
Shannon diversity index is slightly higher in control plots, however the difference is not statistically significant. In the spruce stand the number of species in control and treatment plots did not differ much -6 species were observed in control plots and 7 species were observed in treatment plots. Shannon diversity index is slightly higher in control plots, however differences are not statistically significant.

Frequently observed species in the herb layer of this forest type are Vaccinium myrtillus, Vaccinium vitis-idaea, Calamagrostis arundinacea, Calamagrostis canescens, Calamagrostis epigeios, club-moss Lycopodium annotinum, Maianthemum bifoliu, Molinia caerulea and Rubus saxatilis. In the herb layer of the surveyed birch stand in control plots Carex is the dominant genus, whereas in treatment plots grasses of Festuca genus predominate. In both control and treatment plots Agrostis canina is a frequently observed species, which is typical to wet habitats, acidic soils low in nitrogen and grows in full light. Its occurrence and cover is does not seem to be affected by application of fertilizers. Athyrium filix-femina, Cirsium oleraceum, Galium palustre, Cirsium heterophyllum, Lycopus europaeus, Solanum dulcamara indicate wet growing conditions. Lycopus europaeus and Solanum dulcamara also are nitrophilous species and were observed as solitary individuals only in treatment plots. The nitrophilous ruderal Urtica dioica was observed only in the spruce stand and its projective cover was larger in treatment plots. Other frequently observed species in the spruce stand were Geranium robertianum, Rubus idaeus, Stellaria media, Veronica chamaedrys, Mycelis muralis and Dryopteris carthusiana. The projective cover of the last two was low. Nitrophilous Stellaria media forms a larger cover in treatment plots. In the birch stand Stellaria media, which is typical to nutrient-rich, mildly acidic to alkaline soils and was observed only in treatment plots, whereas in the spruce stand it was also observed as solitary individuals with low projective cover in control plots. Only in the birch stand in treatment plots Ranunculus repens was observed. In the birch stand the total number of herb species in control plots was 31, but in treatment plots -28 . The average Shannon diversity index is significantly larger in control plots than in treatment plots $(\mathrm{p}=0.0061)$. In the herb layer of the spruce stand the most frequently observed species were Dryopteris carthusiana, Geranium robertianum, Mycelis muralis, Fragaria vesca, Stellaria media and Urtica dioica. Surprisingly those species, even the nitrophiles, were more frequently observed in control plots. Only in control plots Veronica officinalis, Trientalis europaea, Taraxacum officinale, Oxalis acetosella, Deschampsia caespitosa, Anthriscus sylvestris, Athyrium filix-femina were observed. Only in treatment plots Viola uligionsa, Ranunculus auricomus, Phragmites australis, Melampyrum nemorosum, Melampyrum pratense, Angelica sylvestris and Agrostis canina were observed. In the spruce stand the number of species did not differ much between control and treatment plots. The average Shannon diversity index in control plots is 1.83, but in treatment plots it is 1.64 , however the difference is not statistically significant (Table 3). In the shrub layer Betula pubescens and Frangula alnus were observed in the spruce stand and Picea abies - in the birch stand.

\section{Vacciniosa mel. forest stand}

Vacciniosa mel. belongs to oligomesotrophic ecosystems. The typical mosses of this forest type are Pleurozium schreberi, Hylocomium splendens, Dicranum sp., Rhytidiadelphus sp., Polytrichum commune. In the moss layer of the surveyed Vacciniosa mel. stand the dominant species in both control and treatment plots were ubiquitous Hylocomium splendens and Pleurozium schreberi. Only in treatment plots Dicranum majus, Plagiomnium affine, Rhytidiadelphus squarrosus, Sphagnum girgensohnii were observed. Species richness in the moss layer was slightly higher in treatment plots, whereas species diversity was low in both control and treatment plots and there were no statistically significant differences (Table 3). The typical species in the herb layer are Vaccinium myrtillus, Vaccinium vitis-idaea, Molinia caerulea, Calamagrostis canescens, Calamagrostis epigeios, Calamagrostis arundinacea, Lycopodium annotinum, Maianthemum bifolium, Rubus saxatilis, Anemone nemorosa. The dominant species in the herb layer were dwarf shrubs Vaccinium myrtillus and Vaccinium vitis-idaea. Only in control plots Anemone nemorosa as well as Athyrium filix-femina, and Phragmites australis, which indicate locally wet habitat, were observed. Only in treatment plots mesotrophic and oligomesotrophic habitat species Convallaria majalis and Luzula pilosa, species that prefer higher nutrient content and mildly acidic to neutral growing conditions: Equisetum pratense, Lathyrus vernus, Rubus saxatilis, nitrophiles Mycelis muralis, Oxalis acetosella, as well as species prefering both high nitrogen levels and soil $\mathrm{pH}$ - Galium aparine and Stellaria media - were observed. Calamagrostis arundinacea, which grows on nutrient-rich soils low in calcium, and Molinia caerulea were more frequently observed in control plots. Nitrophilous Rubus idaeus and Trientalis europaea were more frequently observed in treatment plots. Both species richness and species diversity are higher in treatment plots, however differences are not statistically significant (Table 3). The shrub layer consists of Betula pendula, Frangula alnus, Picea abies, Pinus sylvestris, Salix sp. and Sorbus aucuparia. The overall species composition correspond to the respective forest type.

\section{Vacciniosa turf. mel. forest stand}

Vacciniosa turf. mel. belongs to mesoeutrophic ecosystems. The typical mosses of this forest type are Pleurozium schreberi, Dicranum sp., Hylocomium splendens, Ptilium crista-castrensis, Sphagnum sp.. In the moss layer of the surveyed Vacciniosa turf. mel. stand the dominant species were Pleurozium schreberi and Hylocomium splendens. Frequently observed species also were Aulacomnium palustre and Dicranum polysetum. Aulacomnium palustre is not typical to this forest type and indicates moist environment. Also Ptilium crista-castrensis, which is rarely observed in Latvia and is typical to moist habitats. All the previously mentioned mosses are more frequently observed in control plots. Only in control plots Sphagnum girgensohnii was observed, which is normally observed in wet forests. Only in treatment plots Dicranum scoparium was observed. The species richness slightly lower in treatment plots, whereas the average Shannon diversity index significantly lower in treatment plots $(\mathrm{p}=0.00056)$ (Table 3). The typical species in the herb layer 
of this forest type are Vaccinium myrtillus, Vaccinium vitis-idaea, Melampyrum sp., Luzula pilosa, Molinia caerulea, Calamagrostis canescens, Calamagrostis epigeios, Lycopodium annotinum, Maianthemum bifolium. In the herb layer of the surveyed stand the dominant species was dwarf shrub Vaccinium vitis-idaea. Dwarf shrubs Ledum palustre (typical to wet habitats), Calluna vulgaris as well as Melampyrum pratense were more frequently observed in control plots, whereas in treatment plots Vaccinium uliginosum and Vaccinium myrtillus were more frequently observed. Only in control plots the fern of mesoeutrophic habitats - Dryopteris carthusiana and Luzula Pilosa were observed. Only in treatment plots the orchid Goodyera repens, as well as nitrophiles Rubus idaeus and Urtica dioica were observed. Species richness did not differ much between control and treatment, it is slightly higher in treatment plots (34 species un control plots and 38 species in treatment plots). Shannon diversity index is significantly lower in treatment plots ( $\mathrm{p}=0.029)($ Table 3 ). The undergrowth consists of Betula pubescens and Frangula alnus. The overall species composition corresponds to Vacciniosa turf. mel. forest type.

Table 3: Values of Shannon diversity index (H') and species richness (the number of species) in control and treatment plots

\begin{tabular}{|c|c|c|c|c|c|c|c|c|c|c|c|c|c|}
\hline \multirow[t]{3}{*}{ Forest type } & \multirow{3}{*}{$\begin{array}{c}\text { Tree } \\
\text { species }\end{array}$} & \multicolumn{6}{|c|}{$\mathrm{H}^{\prime}$} & \multicolumn{6}{|c|}{ Species richness } \\
\hline & & \multicolumn{3}{|c|}{ Control } & \multicolumn{3}{|c|}{ Treatment } & \multicolumn{3}{|c|}{ Control } & \multicolumn{3}{|c|}{ Treatment } \\
\hline & & ML* & $\mathrm{HL}^{*}$ & SL* & ML* & $\mathrm{HL}^{*}$ & SL* & ML* & HL* & SL* & ML* & HL* & SL* \\
\hline $\begin{array}{l}\text { Myrtillosa } \\
\text { mel. }\end{array}$ & $\begin{array}{l}\text { Norway } \\
\text { spruce }\end{array}$ & 1.23 & 2.051 & 0 & 1.010 & 2.026 & 0 & 14 & 37 & 0 & 16 & 39 & 0 \\
\hline $\begin{array}{l}\text { Myrtillosa } \\
\text { mel. }\end{array}$ & $\begin{array}{l}\text { Silver } \\
\text { birch }\end{array}$ & 0.73 & 1.67 & 0.12 & 0.24 & 2.010 & 0 & 8 & 33 & 3 & 6 & 37 & 1 \\
\hline $\begin{array}{l}\text { Myrtillosa } \\
\text { turf. mel. }\end{array}$ & $\begin{array}{l}\text { Silver } \\
\text { birch }\end{array}$ & 0.82 & 1.68 & 0 & 0.22 & 1.12 & 0 & 13 & 31 & 2 & 6 & 28 & 2 \\
\hline $\begin{array}{l}\text { Myrtillosa } \\
\text { turf. mel. }\end{array}$ & $\begin{array}{l}\text { Norway } \\
\text { spruce }\end{array}$ & 0.93 & 1.83 & 0 & 0.77 & 1.64 & 0 & 15 & 25 & 2 & 9 & 24 & 2 \\
\hline $\begin{array}{l}\text { Vacciniosa } \\
\text { mel. }\end{array}$ & $\begin{array}{l}\text { Scots } \\
\text { pine }\end{array}$ & 0.70 & 1.19 & 0.13 & 0.56 & 1.33 & 0.10 & 6 & 17 & 4 & 11 & 23 & 4 \\
\hline $\begin{array}{l}\text { Vacciniosa } \\
\text { turf. mel. }\end{array}$ & $\begin{array}{l}\text { Scots } \\
\text { pine }\end{array}$ & 1.032 & 1.38 & 0.058 & 0.52 & 1.11 & 0.03 & 8 & 34 & 3 & 6 & 38 & 2 \\
\hline
\end{tabular}

*ML-moss layer, HL - herb layer, SL - shrub layer

\section{CONCLUSIONS}

1. The observed impact of application of wood ash and ammonium nitrate on ground vegetation composition is small and species composition is typical of the respective forest types in both control and treatment plots of the surveyed stands. Several moss and herb species observed indicate for a locally wet habitat. In all the forest stands several nitrophilic species either occurred only in treatment plots or were more frequently observed and had a slightly larger projective cover in treatment plots, which could be explained by the impact of fertilization.

2. Wood ash and nitrogen fertilization might have lowered moss diversity. Shannon diversity index values of the moss layer is lower in treatment plots comparing with control plots, however the differences are statistically significant only in cases of Myrtillosa mel. spruce and Myrtillosa turf.mel. birch stands and in Vacciniosa turf. mel. stand. Regarding the herb layer, Shannon diversity index is higher in control plots in Myrtillosa mel. and Myrtillosa turf. mel. stands as well as in Vacciniosa turf. mel. pine stand, whereas for the rest of the stands the species diversity is higher in treatment plots. Regarding the shrub layer the number of species is too low to analyse changes in its diversity, caused by application of fertilizers.

3. In almost all of the surveyed stands species richness in the moss layer was lower in treatment plots, comparing with control plots, except for the Vacciniosa mel. stand and Myrtillosa mel. spruce stand. In case of the herb layer the number of species was larger in treatment plots in Vacciniosa mel., Vacciniosa turf. mel stand and both Myrtillosa mel. stands, while in the rest of the stands it was lower in the plots, where fertilizers were applied. Regarding the shrub layer the number of species is too low to analyse changes in richness, caused by application of fertilizers.

\section{REFERENCES}

1. Arvidsson, H., Vestin T. and Lundkvist H. 2002. Effects of Crushed Wood Ash Application on Ground Vegetation in Young Norway Spruce Stands. Forest Ecology and Management, Vol. 161(1), pp. 75-87. https://doi.org/10.1016/S0378$\underline{1127(01) 00482-0}$

2. Biosafety 2006 Convention Text. Available at https://www.cbd.int/convention/articles/default.shtml?a=cbd-02, (accessed on 16/9/2019).

3. Buriánek, V., Novotný, R., Hellebrandová K. , and Šrámek V., 2013. Ground Vegetation as an Important Factor in the Biodiversity of Forest Ecosystems and Its Evaluation in Regard to Nitrogen Deposition. Journal of Forest Science, Vol. 59 (6), pp. 238-252. https://doi.org/10.17221/16/2013-JFS

4. Dise, N. B., Ashmore, M., Belyazid, S., et al. 2011. Nitrogen as a Threat to European Terrestrial Biodiversity. Available at http://www.nine-esf.org/files/ena_doc/ENA_pdfs/ENA_c20.pdf (accessed on 24/9/2019).

5. Gilliam, F. S. 2007. The Ecological Significance of the Herbaceous Layer in Temperate Forest Ecosystems. BioScience, Vol. 57(10), pp. 845-858. https://doi.org/10.1641/B571007 
6. Jacobson, S. 2003. Addition of Stabilized Wood Ashes to Swedish Coniferous Stands on Mineral Soils - Effects on Stem Growth and Needle Nutrient Concentrations. Silva Fennica 37(4). Available at http://www.silvafennica.fi/article/483 (accessed on 16/09/2019).

7. Jacobson, S., and Lena G. 2001. Effects on Ground Vegetation of the Application of Wood Ash to a Swedish Scots Pine Stand. Basic and Applied Ecology, Vol. 2(3), pp. 233-241. https://doi.org/10.1078/1439-1791-00050

8. Okmanis, M., Skranda, I., Lazdiňš, A., Lazdiņa, D. 2016. Impact of wood ash and potassium sulphate fertilization on growth of Norway spruce stand on organic soil. Proceedings of the Annual 22nd International Scientific Conference „, Research for Rural Development", Vol. 2, pp. 62-68, Latvia University of Agriculture.

9. Olsson, B.A., and Kellner O. 2002. Effects of Soil Acidification and Liming on Ground Flora Establishment after Clear-Felling of Norway Spruce in Sweden. Forest Ecology and Management, Vol. 158(1), pp. 127-139. https://doi.org/10.1016/S03781127(00)00713-1

10. Pitman, R. M. 2006. Wood Ash Use in Forestry - a Review of the Environmental Impacts. Forestry: An International Journal of Forest Research, Vol. 79(5), pp. 563-588. https://doi.org/10.1093/forestry/cpl041

11. Pukkala, T. 2017. Optimal Nitrogen Fertilization of Boreal Conifer Forest. Forest Ecosystems, Vol. 4(1). pp. 3. https://doi.org/10.1186/s40663-017-0090-2

12. Saarsalmi, A., and Mälkönen E. 2001. Forest Fertilization Research in Finland: A Literature Review. Scandinavian Journal of Forest Research, Vol. 16(6), pp. 514-535. https://doi.org/10.1080/02827580152699358

13. Spellerberg, I. F., and Fedor, P. J. 2003. A Tribute to Claude Shannon (1916-2001) and a Plea for More Rigorous Use of Species Richness, Species Diversity and the 'Shannon-Wiener' Index. Global Ecology and Biogeography, Vol. 12(3), pp. $177-179$. https://doi.org/10.1046/j.1466-822X.2003.00015.X

14. Vahdati, F. B., Mehrvarz, S.S., Naqinezhad A., Gholizadeh H. 2016. How plant diversity features change across ecological species groups? A case study of a temperate deciduous forest in northern Iran. Biodiversitas Journal of Biological Diversity, Vol. 15(1). https://doi.org/10.13057/biodiv/d150105

15. Vesterinen P. 2003. Wood ash recycling - state of the art in Finland and Sweden. Research Report, VTT Processes. 